\title{
Cechy sedymentologiczne osadów wodnolodowcowych w żwirowni Łubienica-Superunki (SE części Wysoczyzny Ciechanowskiej)
}

\author{
Sedimentological characteristics of fluvioglacial deposits in the Łubienica-Superunki quarry \\ (SE part of Ciechanowska Upland)
}

\section{Dorota Giriat*, Ewa Smolska, Bartosz Woźniak}

Zakład Geomorfologii, Uniwersytet Warszawski; *dagiriat@uw.edu.pl

\begin{abstract}
Zarys treści: Praca zawiera charakterystykę sedymentologiczną osadów sandrowych występujących pod niewielkiej miąższości gliną lodowcową w południowo-wschodniej części Wysoczyzny Ciechanowskiej, w pobliżu strefy krawędziowej $z$ doliną Narwi. W artykule przedstawiono opis sekwencji struktur sedymentacyjnych widocznych w żwirowni Łubienica-Superunki i próbę interpretacji warunków transportu i depozycji osadów wodnolodowcowych. Występują tu dwa kompleksy osadów, z których dolny był akumulowany w roztoce piaskodennej, a górny w roztoce o większej dynamice przepływów (ze znacznie większym udziałem żwirów) przed nasuwającym się czołem lądolodu.
\end{abstract}

Słowa kluczowe: osady wodnolodowcowe, sedymentacja sandrowa, plejstocen, Wysoczyzna Ciechanowska

\begin{abstract}
This paper presents the sedimentological characteristics of outwash sediments occurring under a glacial till of a small thickness, in the south-eastern part of the Ciechanowska Upland, near the edge of the Narew Valley. The article presents description of the sequence of sedimentation structures visible in the Łubienica-Superunki quarry. There are two complexes of fluvioglacial sediments. The bottom part visible in the studied outcrops were accumulated in sand-bed braided river whilst the upper part of sediments developed in sandy-gravel braided river of a greater flow dynamics (near front of the warta ice sheet margin).
\end{abstract}

Key words: fluvioglacial deposits, outwash sedimentation, Pleistocene, the Ciechanowska Upland

\section{Wstęp}

Badania osadów sandrowych były często wykonywane zarówno na obszarze współczesnych rzek proglacjalnych (np. Krüger 1997, Russel, Marren 1999, Sambrook-Smith 2000, Kjær i in. 2004), jak i starszych plejstoceńskich (np. Zieliński 1993, Pisarska-Jamroży 2008). Rozpoznane zostały cechy charakterystyczne dla sedymentacji w strefach proksymalnej, środkowej i dystalnej na sandrach (Zieliński 1993, Zieliński, van Loon 2003). Zwracano uwagę na charakterystyczne zespoły litofacji $\mathrm{w}$ osadach sandrowych, wskazując na ich znaczenie w interpretacji lokalnych warunków subśrodowisk sedymentacji oraz ponadlokalnych, uwarunkowanych klimatycznie. Każde kolejne odsłonięcie daje możliwość lepszego poznania warunków hydrodynamicznych na przedpolu lądolodów plejstoceńskich i tym samym specyfiki (zróżnicowania) warunków transportu i depozycji w dawnych strefach proglacjanych.

Celem prowadzonych badań $\mathrm{w}$ żwirowni Łubienica-Superunki jest rozpoznanie osadów piaszczysto-żwirowych, występujących w nich struktur sedymentacyjnych oraz rekonstrukcja środowiska sedymentacji. Wyniki przeprowadzonych badań dostarczą nowych danych na temat dynamiki odpływu wód lodowcowych na północnym Mazowszu podczas stadiału warty, zlodowacenia odry.

Prac poruszających problem sedymentacji osadów w tej części Mazowsza jest niewiele. Większość dotyczy uwarunkowań geologicznych i geomorfologicznych rozwoju rzeźby (Michalska 1961, Różycki 
1972, Baraniecka 1979, Bałuk 1991, Grabińska, Kubeł 2011). W ostatnim czasie rozpoznanie utworów geologicznych na omawianym fragmencie terenu prowadzone jest przez Państwowy Instytut Geologiczny (Frankiewicz 2017).

\section{Obszar badań}

Żwirownia Łubienica-Superunki położona jest w województwie mazowieckim, na południe od Pułtuska. W podziale fizycznogeograficznym Polski (Kondracki 2000) obszar badań usytuowany jest w obrębie Niziny Północnomazowieckiej, w południowo-wschodniej części Wysoczyzny Ciechanowskiej (ryc. 1).

Teren badań znajduje się na zapleczu moren czołowych stadiału warty, tzw. fazy wierzbickiej (moreny położone na północ od Serocka) (Nowak 1969a, b). Moreny czołowe tego stadiału znajdują się około 10 $\mathrm{km}$ na południe od analizowanej żwirowni. Kolejne ciągi morenowe występują na północ od żwirowni w okolicy Makowa Mazowieckiego i Różana. Należą one do ciągu wzniesień morenowych korelowanych z fazą ciechanowską (Michalska 1967). Pomiędzy tymi ciągami morenowymi znajduje się płaska bądź falista powierzchnia moreny dennej, na której zlokalizowana jest żwirownia.

\section{Metody badań}

Do charakterystyki sedymentologicznej osadów posłużono się kodem litofacjalnym Mialla (1996) w modyfikacji Zielińskiego (1995, 2014). Do analizy cech osadów i interpretacji litogenetycznej wykorzystano opracowania Zielińskiego (1993, 1999, 2014) oraz Zielińskiego i Pisarskiej-Jamroży (2012).

$\mathrm{Z}$ wybranych warstw reprezentujących zarówno drobno-, jak i gruboziarniste osady pobrano próbki. Analizy uziarnienia wykonano standardowymi metodami: sitową i areometryczną. Dla osadów zawierających otoczaki wykonano analizę uziarnienia z zastosowaniem sit oczkowych według Rutkowskiego (1995). Skład granulometryczny przedstawiono w skali Udden-Wentwortha (Udden 1914, Wentworth 1922, za Mycielską-Dowgiałło 1995, 2007).

W celu określenia kierunków paleoprzepływu zmierzono azymuty upadu lamin $\mathrm{w}$ wybranych warstwach (na ścianach eksploatacyjnych, do których był możliwy dostęp). Profile i kierunki paleoprąadów opracowano w aplikacjach SedLog i GeoRose.

Wskaźniki sedymentologiczne, takie jak średnia średnica ziarna $\mathrm{Mz}$ i odchylenie standardowe $\sigma_{1}$, obliczono według Folka i Warda (1957). Zależności między powyższymi wskaźnikami analizowano według Mycielskiej-Dowgiałło (1995, 2007). Wykreślone krzywe kumulacyjne według Vishera (1969)
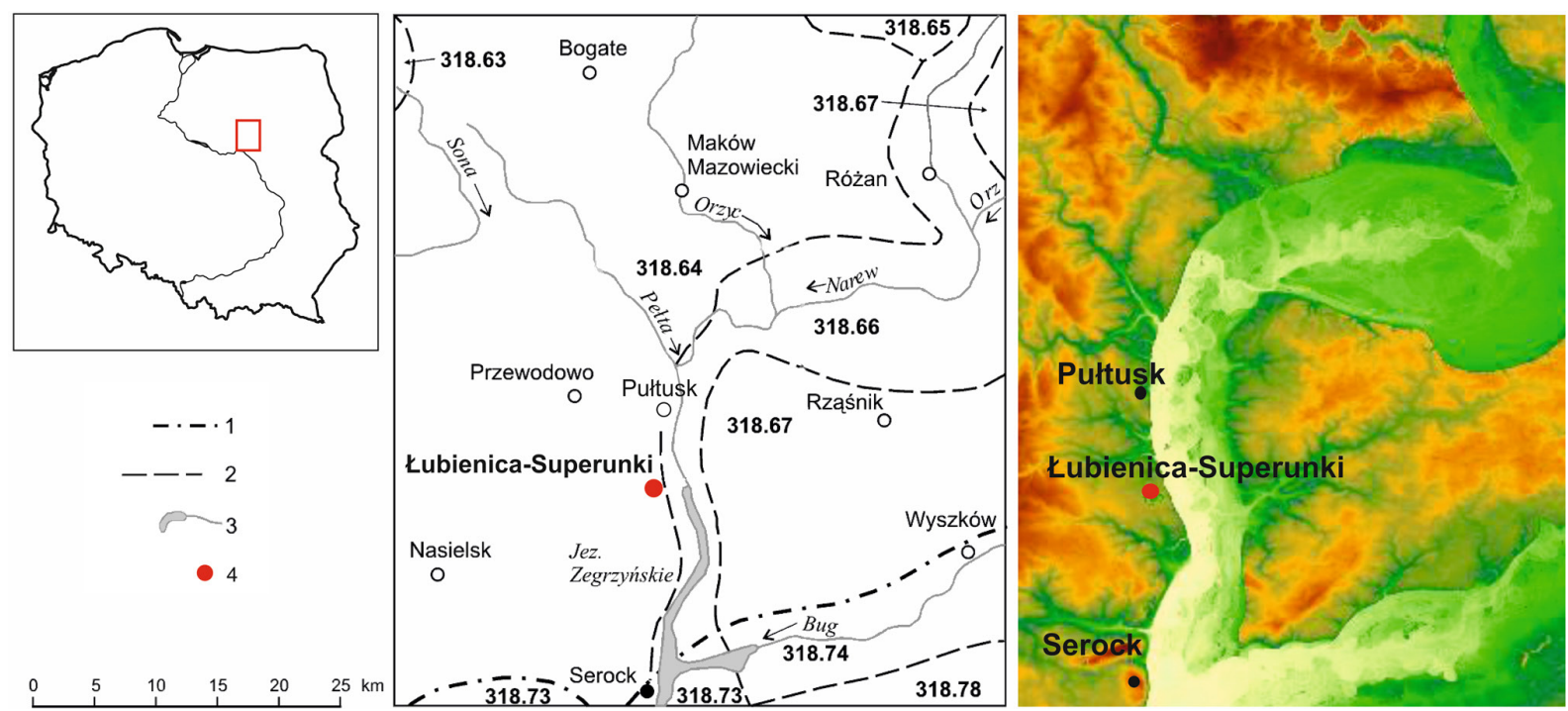

Ryc. 1. Położenie żwirowni na tle jednostek fizycznogeograficznych (Kondracki 2000); wykonano na podstawie: mapy.geoportal.gov.pl/wss/service/wmsimg/guest/ISOK_HipsoDyn/ImageServer/WMSServer

1 - granice makroregionów, 2 - granice mezoregionów, 3 - większe jeziora, 4 - miejsce badań; makroregion: Nizina Północnomazowiecka; mezoregiony: 318.63 - Wzniesienia Mławskie, 318.64 - Wysoczyzna Ciechanowska, 318.65 - Równina Kurpiowska, 318.66 - Dolina Dolnej Narwi, 318.67 - Międzyrzecze Łomżyńskie; makroregion: Nizina Środkowomazowiecka; mezoregiony: 318.73 - Kotlina Warszawska, 318.74 - Dolina Dolnego Bugu, 318.78 - Równina Wołomińska

Fig. 1. Location of the research site on the main of physico-geographic units (Kondracki, 2000); the map elaboration based on the data from: maps.geoportal.gov.pl/wss/service/wmsimg/guest/ISOK HipsoDyn/ImageServer/WMSServer

1 - boundaries of macroregions, 2 - the borders of mesoregions, 3 - larger lakes, 4 - research site; macroregion: North Mazovian Lowland; 318.63 - The Mława Hills, 318.64 - The Ciechanowska Upland, 318.65 - The Kurpiowska Plain, 318.66 - the Lower Narew Valley, 318.67 - The Łomżyńskie Interfluve; macroregion: Central Mazovian Lowlands and mesoregions: 318.73 - the Warsaw Basin, 318.74 - the Lower Bug River, 318.78 - the Wołomin Plain 
miały na celu ustalenie sposobu transportu materiału przed jego depozycją i wielkości ziaren, jakie mogły być transportowane $\mathrm{w}$ trakcji dennej, saltacji czy zawiesinie.

\section{Ogólna charakterystyka osadów występujących w żwirowni}

Według przeprowadzonego rozpoznania złóż surowców mineralnych (Przybylski 1998a, b, 2005a, b, 2007a, b, c, 2008a, b, c, d, e) w okolicach miejscowości Łubienica występują złoża piasków i żwirów. Miąższość ich wynosi od 2 do ponad $20 \mathrm{~m}$ i zwykle są one przykryte nadkładem gliny lodowcowej piaszczystej o niewielkiej miąższości do $0,6 \mathrm{~m}$. W obrębie osadów piaszczysto-żwirowych występują przewarstwienia iłów warwowych oraz osadów zastoiskowych, a także glina lodowcowa i osady ilaste o barwie siwej zaburzone glacitektonicznie (Frankiewicz 2017). Piaski i żwiry są genetycznie określone jako osady wodnolodowcowe $z$ recesji starszego i transgresji młodszego stadiału warty (Frankiewicz 2017) lub fazy wierzbickiej stadiału warty, zlodowacenia środkowopolskiego (Nowak 1969a, b). Ogólnie występujące w żwirowni Łubienica-Superunki utwory można podzielić na dwa kompleksy: dolny z przewagą piasków oraz górny piaszczysto-żwirowy. Miąższość utworów w żwirowni wynosi od 5 do $17 \mathrm{~m}$. Widoczne w kilku ścianach wśród piasków i żwirów siwe osady ilaste mają postać fałdów. W wielu ścianach znajdują się liczne uskoki i mniejsze struktury deformacyjne.

Osady ilaste, ilasto-mułkowe (zastoiskowe, iłów warwowych), miejscami glina zwałowa rozdzielające dwa kompleksy wodnolodowcowe nie były dobrze widoczne w ścianach żwirowni. Górny kompleks wodnolodowcowy pokrywa nieciągła warstwa gliny zwałowej, która korelowana jest z młodszym stadiałem zlodowacenia odry (Frankiewicz 2017), oraz piaski pokrywowe (Nowak 1969b, Dąbski i in. 2017).

\section{Wyniki badań}

Do szczegółowej analizy osadów wybrano ściany zlokalizowane w SE, NE i SW części żwirowni (ryc. 2). Wybór tych ścian miał na celu ukazanie zróżnicowania występujących osadów zarówno dolnego, jak i górnego kompleksu.

\section{Ściana 1}

Pierwsze $z$ badanych stanowisk zlokalizowane jest w SE części wyrobiska (ryc. 2). Wysokość ściany dochodziła do $10 \mathrm{~m}$ a długość do około $40 \mathrm{~m}$. Występu-

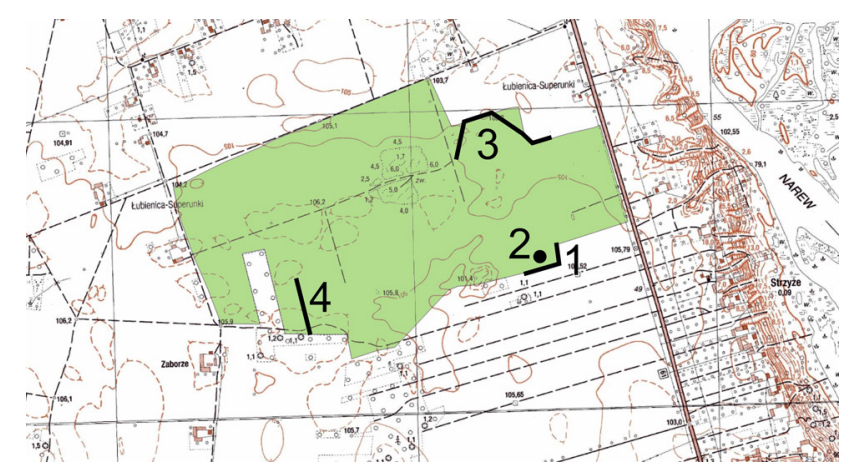

Ryc. 2. Położenie żwirowni Łubienica-Superunki (na podstawie mapy topograficznej 1:10 000; mapy.geoportal. gov.pl)

Linie czarne przedstawiają położenie analizowanych odsłonięć $1-4$

Fig. 2. Location of the Łubienica-Superunki (based on the topographic map 1: 10,000; mapy.geoportal.gov.pl)

Black lines represent the location of the analyzed outcrops 1-4

jące tu osady górnego kompleksu wodnolodowcowego ukazują ryciny 3 i 4 . Na ścianie 1 , w dolnej części, widoczne są osady mułowo-piaszczyste o barwie szaro-beżowej (FSm), miejscami muły piaszczyste warstwowane przekątnie w małej skali (ripplemarki) (Fr) (ryc. 3C, D). Spąg tej warstwy nie jest widoczny. W ich stropie zalegają żwiry masywne Gm lub warstwowane przekątnie GSp (do 0,5 m miąższości). Powyżej występują piaski gruboziarniste warstwowane przekątnie Sp, piaski ze żwirami również warstwowane przekątnie (SGt, SGp) i warstwa wyraźnie drobniejszych piasków masywnych lub warstwowanych poziomo (Sm, Sh). Miejscami mają one znaczną miąższość osiągającą 1,5 m (ryc. 3B). Nad nią występują 5-metrowej miąższości piaski ze żwirami (SGp, SGt) rozdzielone warstwą piasków (Sh), o miąższości od 0,3 do $0,5 \mathrm{~m}$. W południowej części omawianej ściany 1, wśród piasków i żwirów również występują drobniejsze osady (ryc. 4). Pierwszą z warstw piaszczysto-mułowych (SF) stwierdzano około 2,5-3 m od powierzchni, kolejna zalega na głębokości około 8-9 m. Miąższość tych warstw sięga od 0,3 do 0,9 m.

\section{Ściana 2}

Podczas badań możliwe było prześledzenie osadów dolnego kompleksu wodnolodowcowego, położonych prawdopodobnie poniżej osadów zastoiskowych lub gliniastych (ściana 2, ryc. 5A, B, C). Resztki pozio$\mathrm{mu} z$ iłem/gliną widoczne są w nasypie. Występują tu osady piaszczysto-żwirowe. Piaski o jasnej, prawie białej barwie są warstwowane horyzontalnie lub rynnowo. Obocznie w stropie stwierdzono występowanie piaszczystych mułków, wypełniających rozcięcia erozyjne. Ciągłość warstw jest zaburzona licznymi uskokami, przykład jednego $z$ nich ukazuje rycina $5 \mathrm{C}$. 


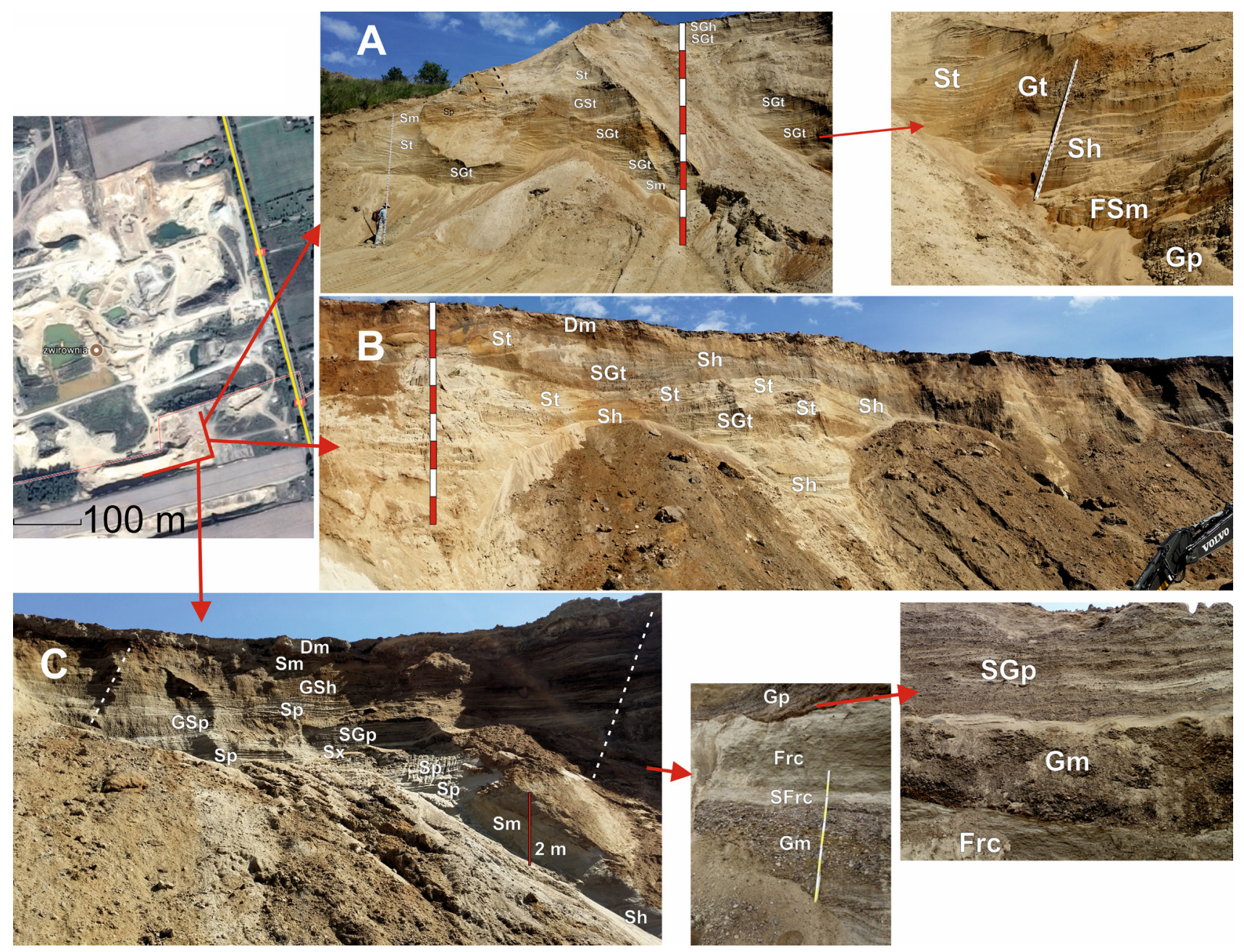

Ryc. 3. Osady fluwioglacjalne w SE części żwirowni Łubienica-Superunki - ściana 1

A-C - fragmenty ściany z zaznaczonymi litofacjami, D - warstwy mułków piaszczystych, E - żwiry i osady piaszczysto-żwirowe nad mułkami; liniami przerywanymi zaznaczono uskoki; fragment ortofotomapy (mapy.geoportal.gov.pl)

Fig. 3. Fluvioglacial sediments in the SE part of the Łubienica-Superunki site - the outcrop 1

A-C the parts of outcrop and visible litofacies, D - layers of sandy loam, E - gravel and sandy-gravel deposits over mud; the dashed lines reflects fault lines; the orthophotomap (mapy.geoportal.gov.pl)

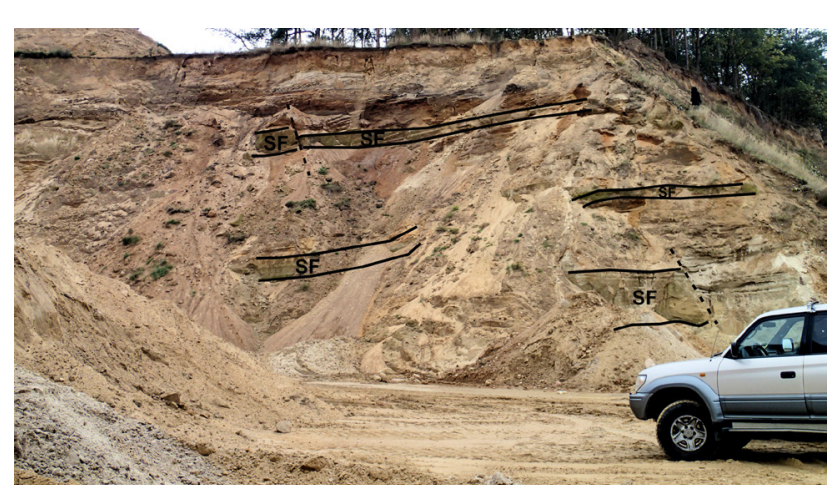

Ryc. 4. Warstwy osadów piaszczysto-pylastych pomiędzy piaskami i piaskami ze żwirem w południowej części ściany $1 \mathrm{w}$ żwirowni Łubienica-Superunki; liniami przerywanymi zaznaczono uskoki

Fig. 4. Layers of sandy-silt sediments between sand and sandy-gravels, in the southern part of 1st outcrop in the Łubienica-Superunki site; the dashed lines reflects fault lines

\section{Ściana 3}

W części północno-wschodniej żwirowni (ryc. 2) widoczne były piaski i żwiry, wyróżniające się rudą barwą, o zaburzonym ułożeniu oraz z bryłą piasków (ryc. $6 \mathrm{~A}, \mathrm{~B})$. Od dołu na ścianie $3 \mathrm{w}$ jej części wschodniej widoczne są piaski masywne (Sm) o miąższości około $4 \mathrm{~m}$. Na nich zalegają piaski warstwowane przekątnie (Sp) o miąższości około $1 \mathrm{~m}$, które ku stropowi warstwy są coraz silniej zażelazione (ruda barwa) i o zaburzonym ułożeniu (ryc. 6 B). W tych piaskach występuje „bryła” zwięzłych piasków silnie zażelazionych (ryc. 6 A). Powyżej wspomnianej „bryły” zalegają żwiry i piaski warstwowane przekątnie i masywne (GSp, GSm) o łącznej miąższości do 1,2 m (ryc. 6C). $\mathrm{W}$ ich spągu miejscami widoczne były rozmycia wypełnione otoczakami, z których największy miał wymiary $13 \times 10 \times 8 \mathrm{~cm}$. Nad żwirami znajdują się muly i piaski masywne (Fm, SFm, Sm). Kolejne warstwy są piaszczyste. Wśród nich występują litofacje $\mathrm{Sr}, \mathrm{Sp}, \mathrm{Sl}$, 

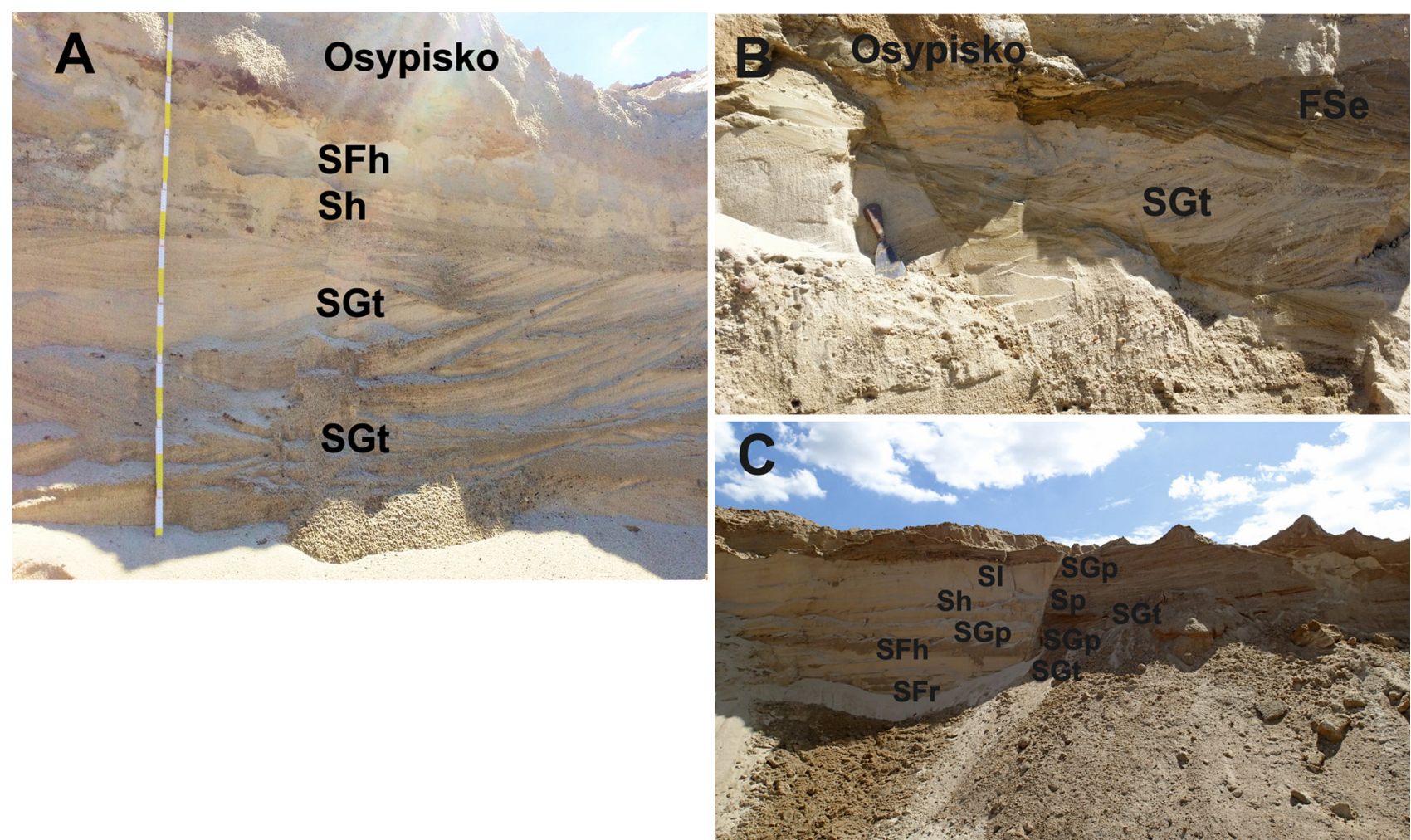

Ryc. 5. Ściana 2 w żwirowni Łubienica-Superunki - kompleks dolny; wybrane fragmenty ściany od jej zachodniej części ku wschodowi

A - typowe osady piaszczysto-żwirowe kompleksu dolnego, B - piaszczyste mułki wypełniające rozcięcia erozyjne i deformacje nieciągłe, C - przykład uskoków występujących w kompleksie dolnym

Fig. 5. The outcrop 2 in the Łubienica-Superunki site - the lower complex of deposits; selected outcrops from West to East A - typical sandy-gravel deposits of the lower complex, B - sandy-silts filling the erosional channel and fault lines, C - example of faults occurring in the lower complex
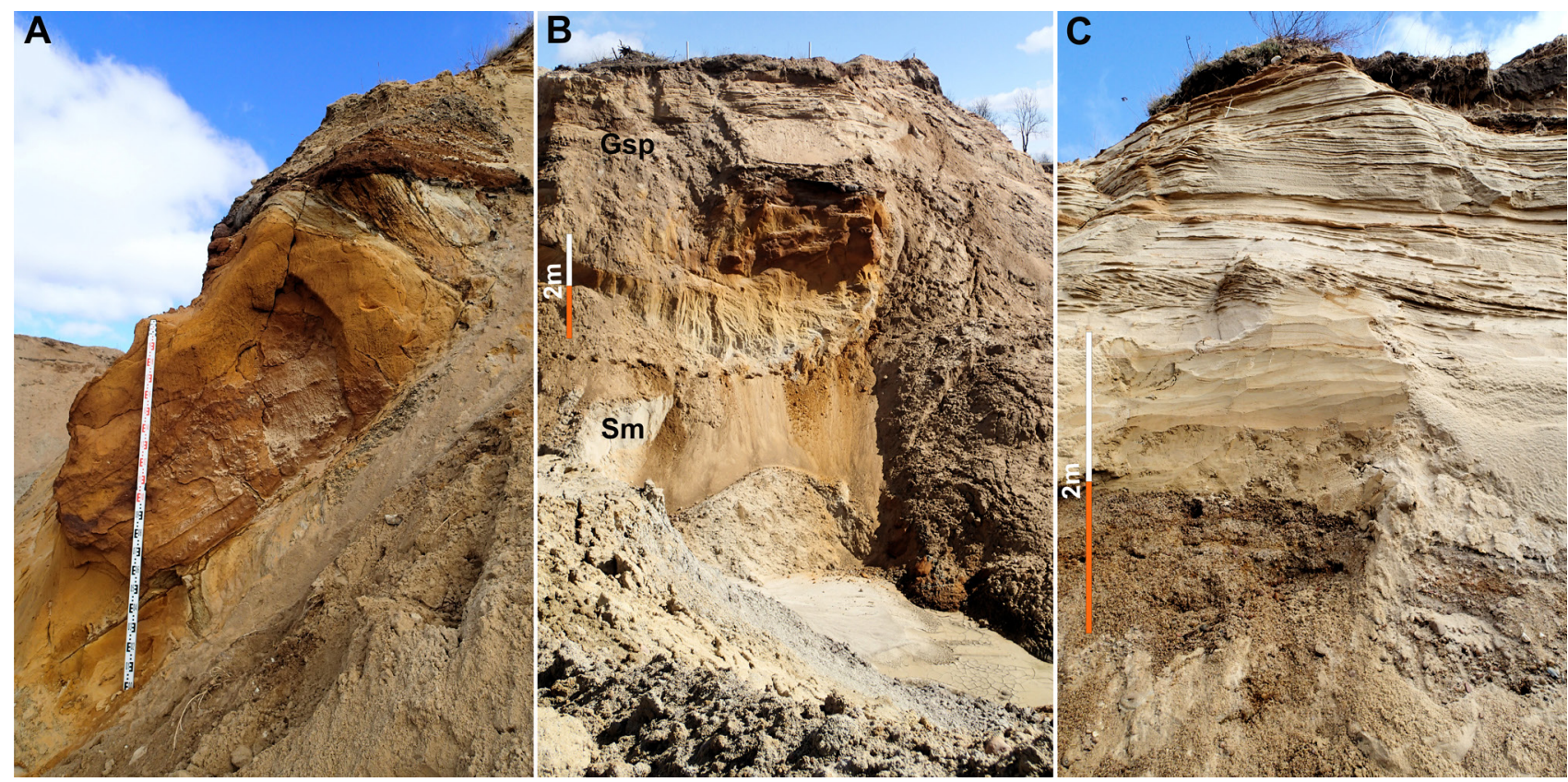

Ryc. 6. Struktury deformacyjne i osady widoczne w ścianie $3 \mathrm{w}$ żwirowni Łubienica-Superunki

A - „bryły piasków” i ich kontakt z osadami nadległymi, B - ogólny widok na ścianę 3, C - osady powyżej oraz w sąsiedztwie deformacji

Fig. 6. The deformation structures and deposits visible in the outcrop 3 in the Łubienica-Superunki site

A - "solid body of sands" and their contact with overlying sediments, B - general view of the outcrop 3, C - deposits above and near the deformation 


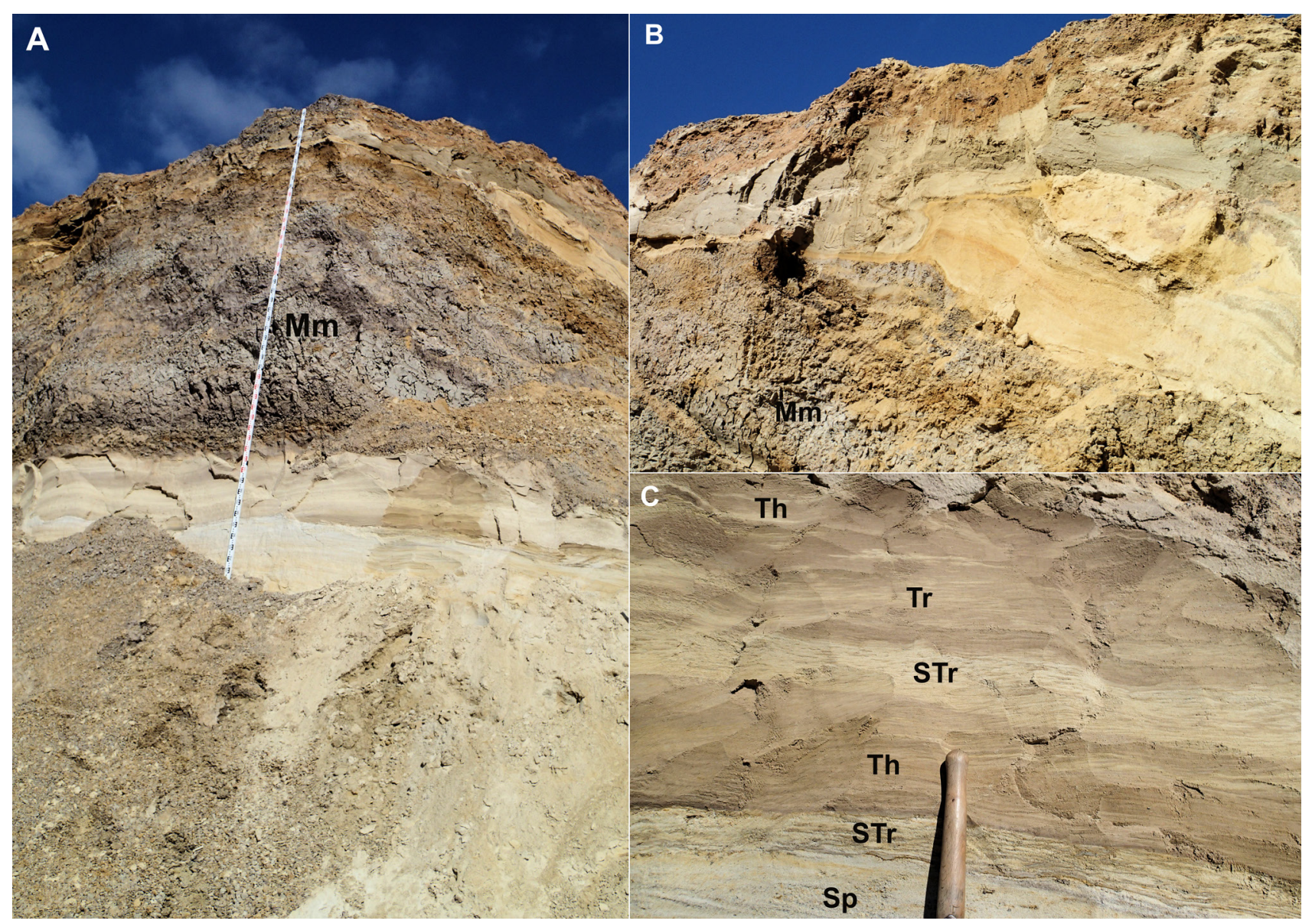

Ryc. 7. Osady widoczne w ścianie 3 w żwirowni Łubienica-Superunki, w części środkowej A - widok ogólny, B - zaburzenia powyżej iłów, C - mułki i piaski pod iłami

Fig. 7. The sediments visible in the outcrop 3 in the Eubienica-Superunki site, in the middle part A - general view, B - deformation above the clays, C - silts and sands under the clay

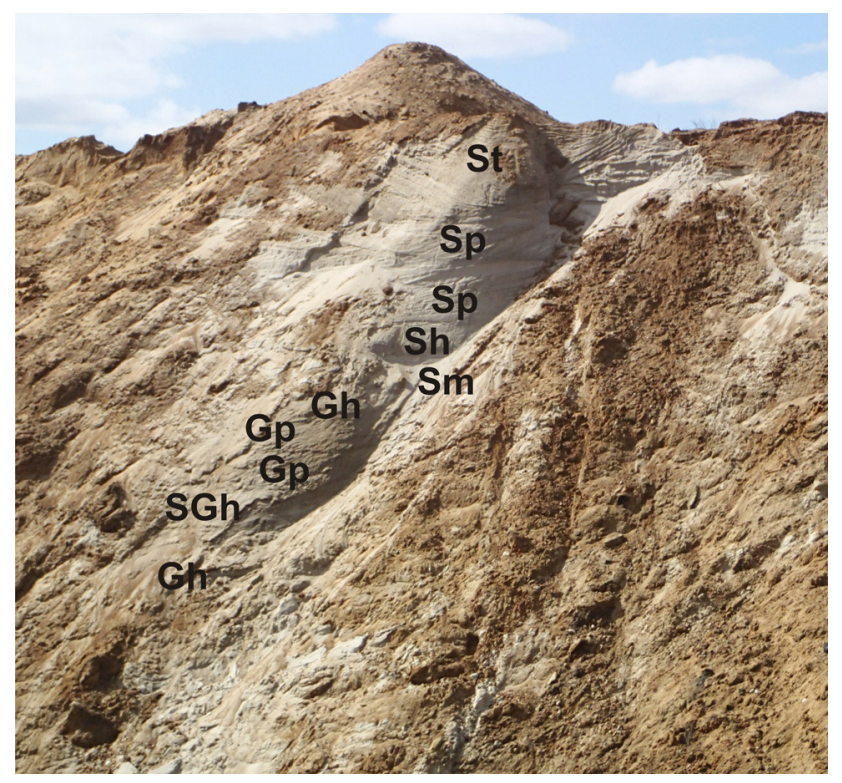

Ryc. 8. Widok na osady w górnej części ściany 3 w żwirowni Łubienica-Superunki; fragment zachodni

Fig. 8. The general view of the sediments in the upper part of the outcrop 3 in the Eubienica-Superunki site; western section rzadziej Sh (ryc. 6C). W stropie zalegają piaski różnoziarniste $z$ pojedynczymi głazikami. Pakiet deformacji erozyjnie wyrównany w stropie najprawdopodobniej położony jest na granicy pomiędzy osadami dolnego i górnego kompleksu wodnolodowcowego (ryc. 6A). Warstwa zdeformowanych iłów siwych występujących w żwirowni, o których wspomniano przy ogólnym omówieniu osadów, jest widoczna w centralnej części ściany 3 (ryc. 2). Przykrywa ona piaski warstwowane przekątnie i muły warstwowane przekątnie w małej skali (ripplemarki) (ryc. 7A, C). Powyżej nich stwierdzono zdeformowane piaski i muł siwy (ryc. 7B). W dalszej części omawianej ściany żwirowni o przebiegu NE-SW (ryc. 2) występują piaski i muły o łącznej miąższości około 4-5 m, a powyżej - piaski ze żwirem i piaski przeważnie warstwowane przekątnie (SGp, Sp), rzadziej pojawia się warstwowanie poziome czy masywne (ryc. 8). Poszczególne warstwy mają znaczną miąższość do 1-1,5 m. W litofacjach SGh, SGp zalega jedynie żwir drobny i średni, co odróżnia je od prezentowanych osadów górnego kompleksu wodnolodowcowego. Te cechy skłaniają do zaklasyfikowania osadów raczej do dolnego kompleksu. 


\section{Ściana 4}

Kolejna ściana zlokalizowana w SW części żwirowni ma 17 m wysokości (ryc. 2). W jej dolnej części występuje prawie metrowej miąższości warstwa mułów. Wyżej znajduje się czterokrotnie powtarzający się zespół litofacji: SGp/SGt $\Rightarrow \mathrm{St} / \mathrm{Sp} \Rightarrow \mathrm{Sh}(\mathrm{SFr})$ (ryc. 9). Miąższość poszczególnych warstw kształtuje się $\mathrm{w}$ granicach około $1 \mathrm{~m}$. Litofacja Sh jest w tych sekwencjach coraz drobniejsza ku górze, a najwyższa warstwa drobnoziarnista jest masywna i zawiera znaczą domieszkę mułków (FSm). Taki powtarzający się zespół litofacji o drobniejącym ziarnie można obserwować na całej ścianie o długości prawie $30 \mathrm{~m}$. Lokalnie zmniejsza się udział jednostek typu SGt, St, a zwiększa Sp i Sh i SFh, pojawiają się też jednostki Sm, SFm. Położenie powyżej mułów i duże zróżnicowanie serii pod względem frakcji, udział grubych

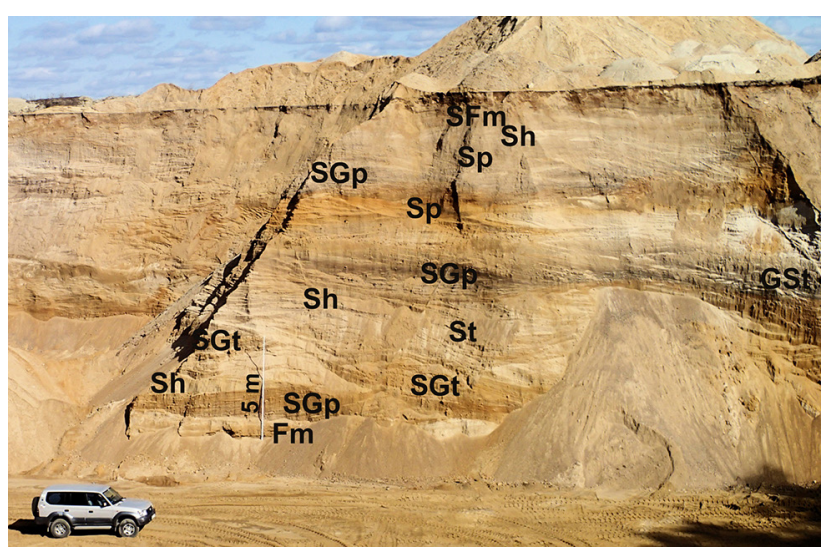

Ryc. 9. Ściana 4 w SW części żwirowni Łubienica-Superunki - widok ogólny

Fig. 9. The outcrop 4 in the SW part of the ŁubienicaSuperunki site - the general view żwirów z domieszką pojedynczych drobnych otocza-

Tabela 1. Wybrane charakterystyki sedymentologiczne (objaśnienia w tekście)

Table 1. Selected sedimentological characteristics of deposits (explanation in text)

\begin{tabular}{|c|c|c|c|c|c|c|c|}
\hline \multirow{2}{*}{\multicolumn{2}{|c|}{$\begin{array}{l}\text { Lokalizacja/ } \\
\text { Litofacje } \\
\text { Location/ } \\
\text { Lithofacies }\end{array}$}} & $\begin{array}{l}\text { Punkt } \\
\text { Point } \\
\text { CT }\end{array}$ & $\begin{array}{l}\text { Punkt } \\
\text { Point } \\
\text { FT }\end{array}$ & $\begin{array}{l}\text { Maksymalne } \\
\text { ziarno } \\
\text { Maximum grain }\end{array}$ & $\begin{array}{c}\text { Średnia średnica } \\
\text { ziarna } \\
\text { Mean grain diameter } \\
(\mathrm{Mz})\end{array}$ & $\begin{array}{c}\text { Odchylenie } \\
\text { standardowe } \\
\text { Standard } \\
\text { deviation }\left(\delta_{1}\right) \\
\end{array}$ & $\begin{array}{c}\text { Skośność } \\
\text { Skewness } \\
\text { Sk }\end{array}$ \\
\hline & & \multicolumn{6}{|c|}{ [phi] } \\
\hline \multicolumn{8}{|c|}{ Ściana 1/Outcrop 1} \\
\hline SG & & - & 2,0 & $-4,00$ & $-0,54$ & 1,57 & $-0,16$ \\
\hline $\mathrm{SG}_{\mathrm{p}}$ & & 0,80 & 3,0 & $-3,00$ & 1,94 & 0,73 & $-0,20$ \\
\hline SGH & & 0,25 & 3,0 & $-1,00$ & 0,74 & 1,56 & $-0,46$ \\
\hline SGt & & 0,00 & 2,0 & $-3,00$ & 2,23 & 0,87 & $-0,20$ \\
\hline Sh & & 2,25 & 4,5 & 0,00 & 3,36 & 0,59 & 0,22 \\
\hline Sh & & 2,25 & 4,5 & $-1,00$ & 1,20 & 0,60 & 0,09 \\
\hline Sp & & - & - & 0,00 & 1,64 & 0,67 & 0,04 \\
\hline \multicolumn{2}{|c|}{ GSm } & 0,50 & 2,0 & $-5,00$ & $-2,08$ & 2,73 & 0,29 \\
\hline & część A/part A & & & & & & \\
\hline & $\mathrm{FSe}$ & 0,00 & 3,0 & $-1,00$ & 2,87 & 0,67 & 0,18 \\
\hline & SGt & $-0,80$ & 3,0 & $-3,00$ & 1,02 & 0,94 & $-0,13$ \\
\hline & GSx & 0,20 & 3,0 & $-3,00$ & 0,65 & 1,68 & $-0,47$ \\
\hline \multirow{2}{*}{\multicolumn{8}{|c|}{ część B/part B }} \\
\hline & & & & & & & \\
\hline 岁 & $\mathrm{Sl}$ & 0,95 & - & 1,00 & 1,91 & 0,44 & 0,04 \\
\hline$\stackrel{U}{\Xi}$ & Sh & 1,50 & - & 1,40 & 2,22 & 0,44 & 0,31 \\
\hline อ & Sh & 1,50 & - & 1,30 & 2,29 & 0,44 & 0,28 \\
\hline ๙ָ & SGp & 1,00 & - & 0,30 & 2,09 & 0,60 & 0,12 \\
\hline$\underset{\widetilde{\Xi}}{\widetilde{\pi}}$ & $\mathrm{SFh}$ & 1,00 & - & 0,75 & 2,61 & 0,42 & 0,04 \\
\hline \multirow[t]{6}{*}{ : } & SFl & 2,00 & - & 1,00 & 2,74 & 0,41 & 0,08 \\
\hline & część C/part C & & & & & & \\
\hline & SGp & $-1,50$ & - & $-3,00$ & $-0,02$ & 0,95 & $-0,16$ \\
\hline & SGp & - & - & $-2,00$ & 0,98 & 0,96 & 0,11 \\
\hline & SGt & $-1,00$ & - & $-2,80$ & 0,44 & 0,92 & $-0,07$ \\
\hline & GSp & $-1,00$ & - & $-2,70$ & 0,20 & 0,85 & $-0,10$ \\
\hline \multicolumn{8}{|c|}{ Ściana 3/Outcrop 3} \\
\hline \multicolumn{2}{|c|}{$\mathrm{Sm}$} & $-0,68$ & 2 & -1 & 1,36 & 0,79 & 0,24 \\
\hline \multicolumn{2}{|l|}{ Sl } & - & 3 & -1 & 1,12 & 0,68 & $-0,07$ \\
\hline \multicolumn{2}{|l|}{ Sh } & 1,00 & 4 & 0,32 & 2,53 & 0,48 & 0 \\
\hline \multicolumn{2}{|c|}{$\mathrm{Sm}$} & $-2,00$ & 3 & -2 & 0,57 & 1,16 & $-0,07$ \\
\hline \multicolumn{2}{|l|}{$\mathrm{Sp}$} & - & -1 & 3 & 2,02 & 0,78 & 0,03 \\
\hline
\end{tabular}



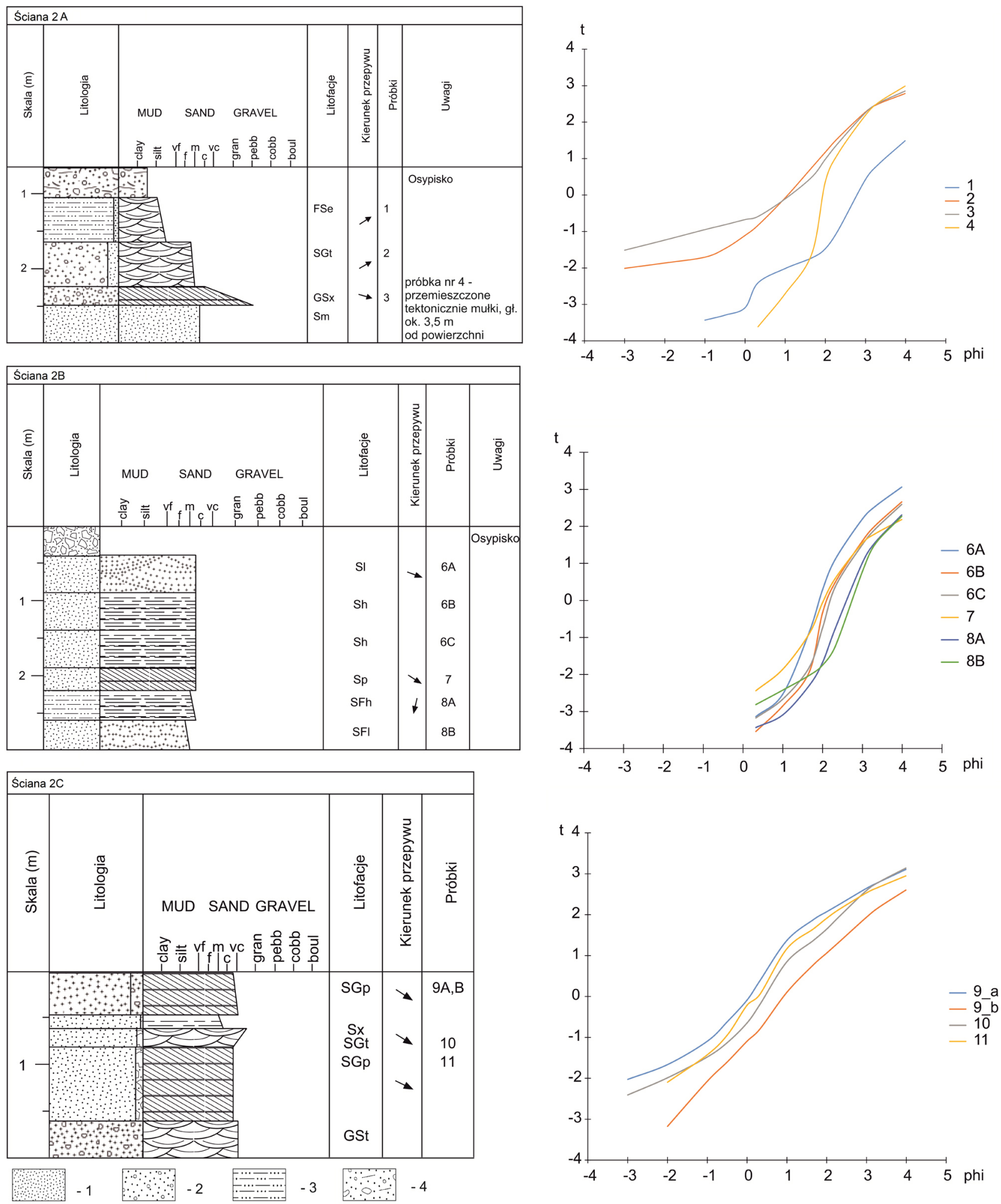

Ryc. 10. Cechy sedymentologiczne osadów dolnego kompleksu wodnolodowcowego w żwirowni Łubienica-Superunki ściana 2, fragmenty ścian pokazane na ryc. $5 \mathrm{ABC}$ 1 - piaski, 2 - żwiry, 3 - mułki, 4 - osypisko

Fig. 10. The sedimentological characteristics of deposits of the lower fluvioglacial complex in the Łubienica-Superunki site - the outcrop 2, the outcrop sections shown on the Fig. 5 ABC

1 - sand, 2 - gravel, 3 - silts, 4 - rubble 
ków w litofacjach SGt, SGp - to typowe cechy wyższego kompleksu wodnolodowcowego.

\section{Warunki sedymentacji osadów wodnolodowcowych}

O warunkach środowiska depozycyjnego można wnioskować na podstawie litofacji i ich genezy wynikającej z dynamiki przepływu oraz charakterystyki form depozycyjnych (Gradziński i in. 1986, Zieliński 1998 , 2014). Dodatkową informację o sposobie transportu materiału przed jego depozycją można uzyskać na podstawie krzywej uziarnienia według Vishera (1969) (np. Ludwikowska-Kędzia 2000, Mycielska-Dowgiałło, Ludwikowska-Kędzia 2011, Szmańda 2011). Zestawiono przykładowe profile sedymentologiczne analizowanych osadów oraz charakterystyczne krzywe uziarnienia dla osadów obu wyróżnionych na podstawie ogólnego rozpoznania kompleksów wodnolodowcowych. W tabeli 1 podano wartości wyliczonych wskaźników sedymentologicznych.

Rycina 10 ukazuje profile dolnego kompleksu. Typowe dla tego kompleksu zespoły litofacjalne to: GSt,SGp,(Sx) lub GSp,SGt (ściana 2) czy SGp,SGh (ściana 3, ryc. 8). Reprezentują one osady koryt o znacznej głębokości z lokalną erozją w dnie, powstałe rozmycia zapełniane były osadem warstwowanym przekątnie. Na dnie koryta formowały się megaripplemarki trójwymiarowe. Taką depozycję uznaje się za charakterystyczną dla centralnych partii koryt aluwialnych (Bridge i in. 1986, Bridge, Lunt 2006). Zieliński (1993) opisał podobną sedymentację w głównym korycie rzecznego systemu sandrowego (np. w Rusi). Większy udział litofacji SGp i Sp (ściana 3) świadczy o powstawaniu znacznych rozmiarów form depozycyjnych - odsypów poprzecznych (Zieliński 1993, 2014). Krzywe kumulacyjne Vishera w przypadku pierwszego i drugiego zespołu litofacjalnego wskazują na transport materiału $\mathrm{w}$ saltacji ze znacznym udziałem trakcji dennej (ryc. 10A, C), w przypadku trzeciego (ryc. 10B) jest to saltacja, a depozycja $z$ trakcji dennej i zawiesiny stanowi nieznaczne domieszki. Występujące rzadziej zespoły litofacjalne: SGh/Sh,Sm wskazują na depozycję w warunkach górnego płaskiego dna. Odpowiadające im krzywe Vishera ukazują głównie populację saltacji (ryc. 10B). Dobre wysortowanie osadu $\left(\delta_{1}=0,42-0,44\right.$ phi) wskazuje na obszar płycizn (powierzchnia odsypów w rzece). Analogiczne krzywe są charakterystyczne dla osadów łach śródkorytowych Wisły (Giriat 2003).

Na podstawie przedstawionych krzywych określono maksymalną wielkość ziarna, graniczną wielkość ziarna rozdzielającą populację trakcyjną od saltacyjnej oraz saltacyjną od zawiesinowej, odpowiednio według punktu CT oraz FT (tab. 1). W niższym kompleksie (ściana 2) w trakcji były transpor-

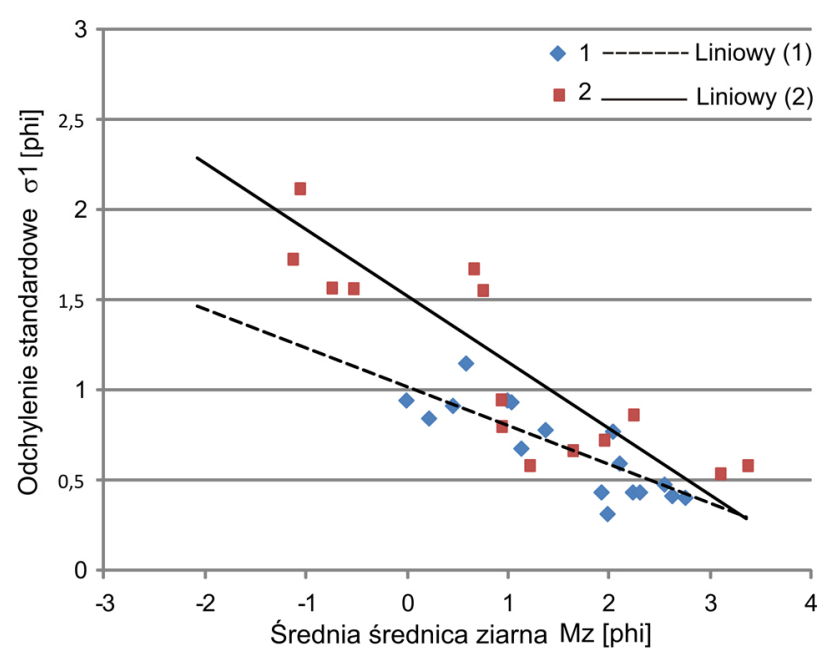

Ryc. 11. Zestawienie średniej średnicy ziarna (Mz) i wysortowania $\left(\delta_{1}\right)$ dla osadów w żwirowni Łubienica-Superunki

1 - osady dolnego poziomu, 2 - osady górnego poziomu

Fig. 11. Comparison of mean grain diameter $(\mathrm{Mz})$ and sorting $\left(\delta_{1}\right)$ for sediments in the Eubienica-Superunki site 1 - deposits of the lower complex, 2 - the upper complex deposits

towane ziarna o średnicy od poniżej -3 phi $(8 \mathrm{~mm})$ do 2 phi $(0,25 \mathrm{~mm}), \mathrm{tj}$. żwiru średniego do piasku średnioziarnistego. W zawiesinie przemieszczane były ziarna piasku drobnego i mniejsze, przy czym tylko okresowo i w nieznacznej ilości były deponowane (stanowią $<3 \%$ masy osadu), zazwyczaj transportowane były dalej (brak segmentu B na krzywych kumulacyjnych). Zestawienie średniej średnicy ziarna i wysortowania osadu wskazuje na zależność typową dla dynamicznego środowiska fluwialnego, korytowego - trend 1 (Mycielska-Dowgiałło 1995) (ryc. 11).

Dla osadów wodnolodowcowych górnego kompleksu przedstawiono profil sedymentologiczny i krzywe kumulacyjne ze ściany 1 (ryc. 12). Jego cechą jest znacznie większe zróżnicowanie frakcjonalne osadów, od żwirów z otoczakami do mułów. Najczęściej występują zespoły litofacjalne SGt, SGp oraz Sp, $\mathrm{Sh},(\mathrm{St})$. Osady te były transportowane w saltacji, ze znacznym udziałem trakcji (wyraźnie zaznacza się na krzywych człon populacji łączonej z trakcją). Duży udział warstwowania przekątnego, które jest charakterystyczne dla rzek roztokowych, wskazuje, że depozycja następowała głównie w korycie, rzadziej z zalewów warstwowych (Miall 1977, Zieliński 1993, 2014, Zieliński, van Loon 2003).

Tylko lokalnie obserwowano występowanie zespołu Gm/GSm, GSp, (SGt). W litofacji Gm, w matriksie żwirowo-piaszczystym, znajdowały się otoczaki o średnicy do kilku centymetrów. W spągu takich warstw znajdowano ilaste toczeńce. Takie masywne diamiktony gruboziarniste charakterystyczne są dla krótkiego transportu, dla sandru w strefie 
proksymalnej i świadczą o bliskim położeniu czoła lądolodu/lodowca (Krüger 1993, Johnson, Gillan 1995, Krzyszkowski, Zieliński 2002). Ze względu na przykrycie górnego kompleksu piaszczysto-żwirowego gliną zwałową w Łubienicy-Superunkach, można było spodziewać się $\mathrm{w}$ odsłonięciach większego udziału takich gruboziarnistych litofacji masywnych świadczących o postępującej transgresji lądolodu. Etap nasuwania się lądolodu jest więc słabo zapisany w osadach żwirowni Łubienica-Superunki, jakby brakowało w zapisie strefy proksymalnej sandru.

Natomiast cechą charakterystyczną $\mathrm{w}$ południowej części żwirowni (ściany 1 i 4) jest występowanie sukcesji osadowej o drobniejącym ziarnie GSm/GSt, $\mathrm{GSp} \rightarrow \mathrm{SGt}, \mathrm{SGp} \rightarrow \mathrm{FSm}, \mathrm{Sm}$, Sh. Ku górze takich sukcesji, mułki są zastępowane piaskiem.
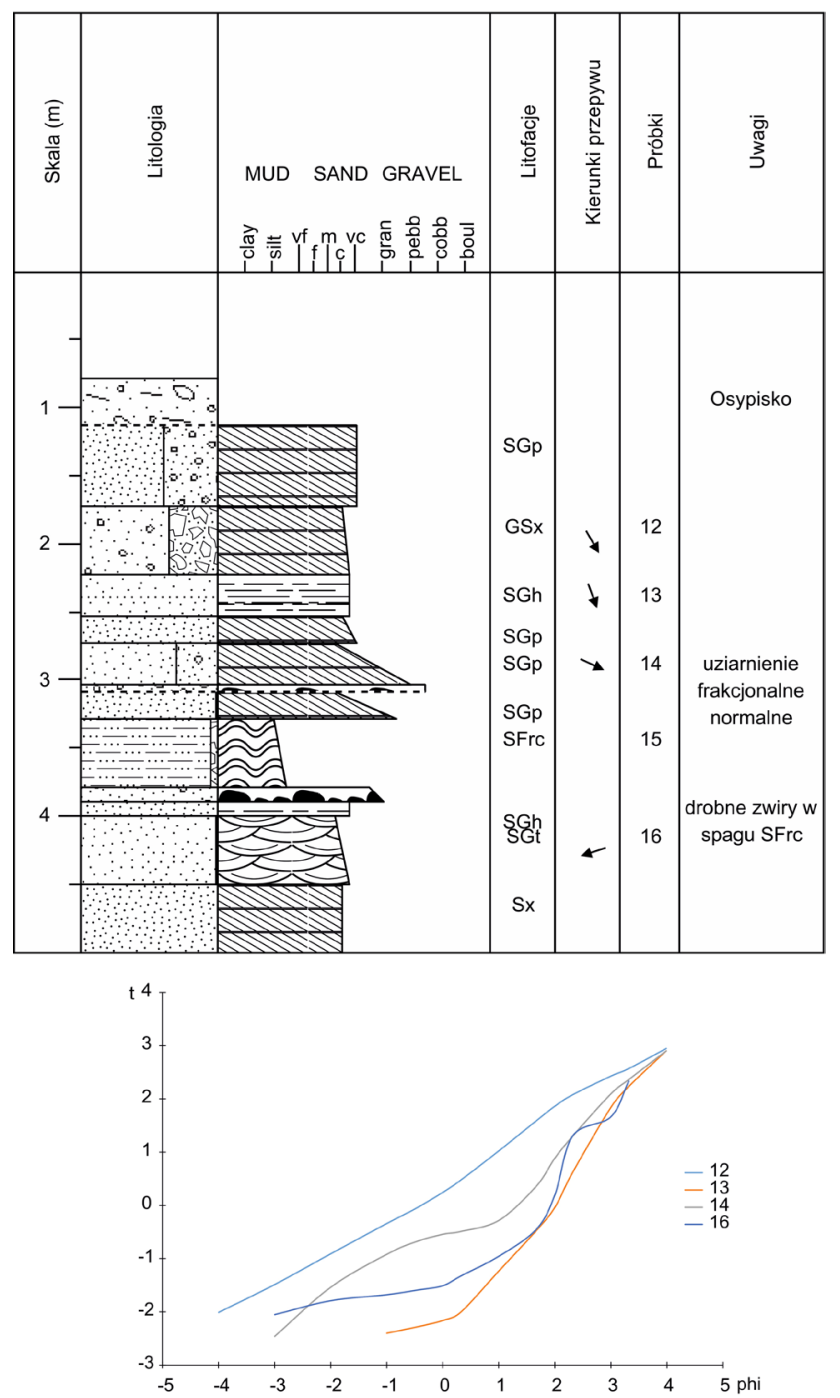

Ryc. 12. Cechy sedymentologiczne osadów z poziomu górnego, ściana SE żwirowni Łubienica-Superunki - ściana 1: stanowisko 3; objaśnienia litologii na ryc. 10

Fig. 12. The sedimentological features of the upper complex deposits, The SE part of the Łubienica-Superunki site the outcrop 1: site 3; lithology specification on the Fig. 10
Na podstawie krzywych uziarnienia można wnioskować, że transport $\mathrm{w}$ trakcji dennej miał większy udział w osadach górnego kompleksu wodnolodowcowego. Ziarno w taki sposób transportowane miało średnice od $-6,5$ phi do 0,8 phi (tab. 1), tj. od małych otoczaków po grube piaski. W zawiesinie transportowane były piaski średnioziarniste wraz z drobniejszymi ziarnami. Frakcje pyłu i iłu stanowiły większe domieszki (do 10\%) niż w dolnym kompleksie (do 3\%). Wykonane analizy uziarnienia wskazują, że transport okresowo zachodził przy dynamicznych przepływach, ponieważ $\mathrm{w}$ trakcji transportowane były otoczaki o średnicy do $-6,5$ phi (oś b otoczaka ponad $32 \mathrm{~mm}$ ) (ryc. 12). Podobne krzywe uziarnienia otrzymano dla osadów w strefie środkowej sandru Flaajökull na Islandii (Smolska i in. 1998).

Diagram ukazujący relacje między średnią średnicą ziarna $\mathrm{Mz}$ a wysortowaniem osadów potwierdza odrębność obu analizowanych kompleksów (ryc. 11). Szczególnie w przypadku osadów o grubszej frakcji, w górnym kompleksie, przy podobnej średniej średnicy ziarna są gorzej wysortowane niż te występujące w dolnym kompleksie, natomiast litofacje piasków (Sh, Sm, Sr) są podobnie wysortowane.

Kierunki paleoprzepływów mieszczą się w sektorze SE (ryc. 13). Przy czym w SE części żwirowni
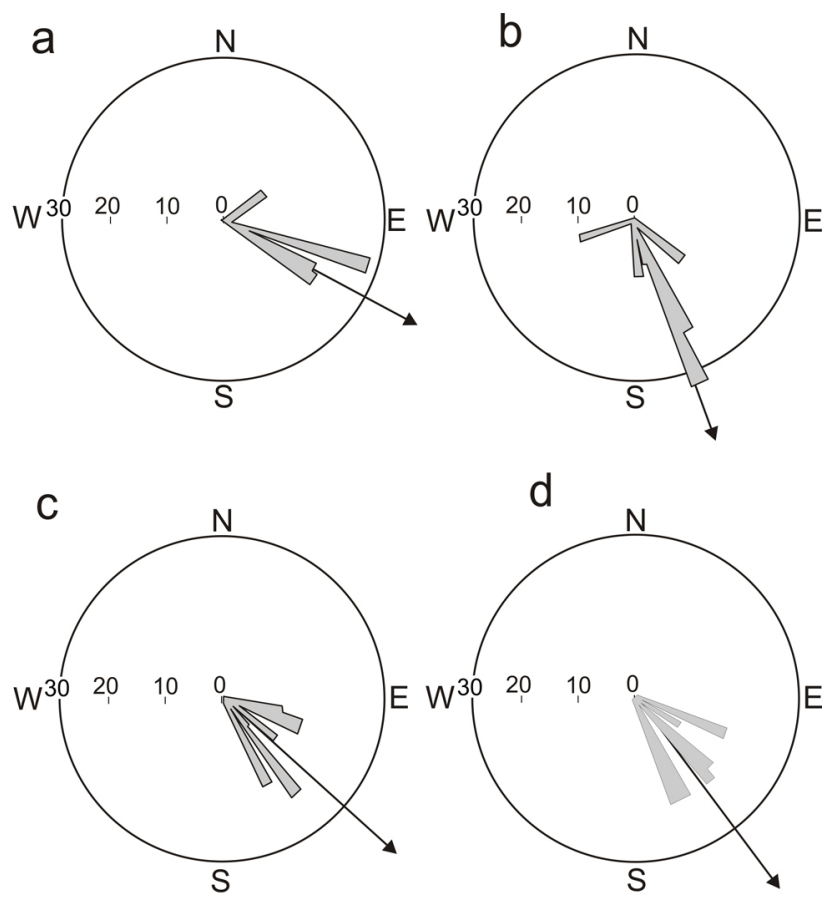

Ryc. 13. Kierunki spływu wód w południowo-wschodniej części żwirowni w poziomie dolnym (ściana 2) (a) i górnym (ściana 1) (b) oraz na pozostałym obszarze w poziomie dolnym (c) i górnym (d)

Fig. 13. The palaeo-current direction of water flow in the south-east part of the quarry, in the lower complex (the outcrop 2) (a) and upper complex (the outcrop 1) (b), and in the other areas in the lower (c) and upper (d) complex 
zaznacza się w dolnym poziome odpływ w kierun$\mathrm{ku}$ ESE, w górnym poziomie $\mathrm{w}$ kierunku SE. Na pozostałym obszarze żwirowni wektor wypadkowy wskazuje podobny kierunek SE, tj. ku dolinie Narwi. Obecnie podobny przebieg mają dopływy Narwi na Wysoczyźnie Ciechanowskiej.

\section{Wnioski}

$\mathrm{Z}$ badań przeprowadzonych $\mathrm{w}$ żwirowni ŁubienicaSuperunki wynika, że odpływ sandrowy kształtował się w 2 odrębnych etapach, którym ogólnie odpowiadają osady kompleksu dolnego i górnego. Oba poziomy można powiązać z rzeką roztokową. Poziom dolny (starszy) można określić jako osady typowe dla roztoki piaskodennej, która funkcjonowała w znacznym oddaleniu od czoła lądolodu. Wskazuje na to przewaga litofacji Sp, SGp, dobre i średnie wysortowanie osadów. Kompleks górny cechuje większa zmienność dynamiki przepływu i zaznaczająca się cykliczność depozycji, o której świadczą 3-4-metrowej miąższości pakiety o drobniejącym ziarnie: od żwirów (GSt, GSp rzadziej Gm) do piasków (SGt,SGp $\rightarrow$ St, Sp) oraz piasków i mułków ( $\mathrm{Sm}, \mathrm{Sh} \rightarrow \mathrm{Sr}$ i SFr).

Powtarzanie się 4-krotnie cyklu o drobniejącym ziarnie (wschodnia część żwirowni) może wskazywać nie tylko na zanikanie przepływu w poszczególnych kanałach w wyniku awulsji, ale również na okresy występowania przepływów o większej energii $\mathrm{i}$ ich stopniowe wygasanie związane $z$ warunkami ablacji lądolodu, być może regionalnymi. Takie cykle zaznaczają się również poprzez zespół litofacjalny GSt, SGp (Sh).

W górnym kompleksie przykrytym gliną zwałową fazy wierzbicy - stadiał warty zlodowacenia środkowopolskiego wg Nowaka (1969 a, b) - brakuje wyraźnego zapisu transgresji.

\section{Literatura}

Bałuk A., 1991. Czwartorzęd dorzecza dolnej Narwi (północno-wschodnie Mazowsze). Prace PIG, Warszawa, 130.

Bridge J.S., Lunt I.A., 2006. Depositional models o braided rivers.W: Barided Rivers: Processes, Deposits, Ecology and Management IAS Spec. Publ. 36: 977-986.

Bridge J.S., Smith N.D., Trent F., Gabel S.L., Bernstein P., 1986. Sedimentology and morphology of a low-sinnuosity river: Calamus River, Nebraska Sand Hills. Sedimentology 33: 851-870.

Baraniecka M.D., 1979. Osady plioceńskie Mazowsza jako podłoże czwartorzędu. Biuletyn Geologiczny Wydz. Geologii UW 23: 23-38.

Dąbski M., Zawadzka-Pawlewska U., Greń K., 2017. Struktury peryglacjalne na stanowisku Łubienica-Superunki (Wysoczyzna Ciechanowska) - wstępne wyniki badań. Landform Analysis 33: $17-24$.
Folk R.L., Ward W.C., 1957. Brazos River bar: a study in the significance of grain size parameters. Journal of Sedimentary Petrology 27: 3-26.

Frankiewicz A., 2017. Materiały robocze do Szczegółowej Mapy Geologicznej Polski w skali 1:50 000, arkusz Serock. PIG, Warszawa.

Giriat D., 2003. Wpływ stopnia wodnego we Włocławku na wybrane cechy tekstualne osadów korytowych Wisły. MS pracy doktorskiej. Archiwum WGSR, UW, Warszawa.

Grabińska B., Kubeł S., 2011. Geneza doliny Narwi i terenów bezpośrednio przyległych $\mathrm{w}$ badaniach geologiczno-geomorfologicznych Polski. Zeszyty Naukowe Ostrołęckiego Towarzystwa Naukowego 25: 53-61

Gradziński R., Kostecka A., Radomski A., Unrug R., 1986. Zarys sedymentologii. Wydawnictwo Geologiczne, Warszawa

Johnson M.D., Gillam M.L., 1995. Composition and construction of late Pleistocene end Moraines, Duyrango, Colorado. Geological Society America Bulletin 107(10): 1241-1253.

Kjær K.H., Sultan L., Krüge J., Schomacker A., 2004. Architecture and sedimentation of outwash fans in front of the Myrdalsjökull ice cap, Iceland. Sedimentary Geology 172: 139-163.

Kondracki J., 2000. Geografia fizyczna Polski. PWN, Warszawa.

Krüger J., 1997. Development of minor outwash fans at Kötulujökull, Iceland. Quaternary Science Reviews 16: 649-659.

Krzyszkowski D., Zieliński T., 2002. The Pleistocene and moraline fans: controls an their sedimentation and locatio. Sedimentary Geology. 149: 73-92.

Ludwikowska-Kędzia M., 2000. Ewolucja środkowego odcinka doliny Belnianki w późnym glacjale i holocenie. Wydawnictwo Akademickie Dialog, Warszawa: 1-181.

Miall A.D., 1996. The Geology of Fluvial Deposits. Sedimentary Facies, Basin Analysis and Petroleum Geology. Springer, Berlin.

Michalska Z., 1961. Stratygrafia plejstocenu i paleomorfologia północno-wschodniego Mazowsza. Studia Geologia Polonica 7.

Mycielska-Dowgiałło E., 1995. Wybrane cechy teksturalne osadów i ich wartość interpretacyjna. W: E. Mycielska-Dowgiałło, J. Rutkowski (red.), Metody badań osadów czwartorzędowych. Wybrane metody i interpretacja wyników. Wydawnictwo WGSR UW, Warszawa: 29-105.

Mycielska-Dowgiałło E., 2007. Metody badań cech teksturalnych osadów klastycznych i wartość interpretacyjna wyników. W: E. Mycielska-Dowgiałło, J. Rutkowski (red.), Badania cech teksturalnych osadów czwartorzędowych i wybrane metody oznaczania ich wieku. Wydawnictwo Szkoły Wyższej Przymierza Rodzin, Warszawa: 95-180.

Mycielska-Dowgiałło E., Ludwikowska-Kędzia M. 2011. Alternative interpretations of grain-size data from Quaternary deposits. Geologos 17(4): 189-203.

Nowak. J.,1969a. Szczegółowa mapa geologiczna Polski, 1:50 000, arkusz Serock.

Nowak J., 1969b. Objaśnienia do Szczegółowej mapy geologicznej Polski, 1:50 000, arkusz Serock.

Pisarska-Jamroży M., 2008. Mechanizmy depozycji w strefie glacimarginalnej zlodowacenia Wisły. Studium sedymentologiczne z Pomorza Zachodniego i Jutlandii. Wydawnictwo UKW, Bydgoszcz.

Przybylski G., 1998a. Dodatek nr 1 do uproszczonej dokumentacji geologicznej w kat. Cl złoża kruszywa naturalnego Łubienica. Centralne Archiwum Geologiczne, Państwowy Instytut Geologiczny - Państwowy Instytut Badawczy, Warszawa.

Przybylski G., 1998b. Uproszczona dokumentacja geologiczna w kat. C1 złoża kruszywa naturalnego Łubienica VII. Centralne Archiwum Geologiczne, Państwowy Instytut Geologiczny - Państwowy Instytut Badawczy, Warszawa.

Przybylski G., 2005a. Dokumentacja geologiczna w kat. C1 złoża kruszywa naturalnego Łubienica XI. Centralne Archiwum Geologiczne, Państwowy Instytut Geologiczny - Państwowy Instytut Badawczy, Warszawa.

Przybylski G., 2005b. Dokumentacja geologiczna złoża kruszywa naturalnego (piasków) Łubienica Superunki w kat. C1. Central- 
ne Archiwum Geologiczne, Państwowy Instytut Geologiczny Państwowy Instytut Badawczy, Warszawa.

Przybylski G., 2007a. Dodatek nr 4 do dokumentacji geologicznej (uproszczonej) w kat. Cl złoża kruszywa naturalnego Łubienica IV - pole A. Centralne Archiwum Geologiczne, Państwowy Instytut Geologiczny - Państwowy Instytut Badawczy, Warszawa.

Przybylski G., 2007b. Dodatek nr 1 do dokumentacji geologicznej w kat. Cl złoża kruszywa naturalnego (piasku z domieszką żwiru) Łubienica X. Centralne Archiwum Geologiczne, Państwowy Instytut Geologiczny - Państwowy Instytut Badawczy, Warszawa.

Przybylski G., 2007c. Dodatek nr 2 do dokumentacji geologicznej w kat. C1 złoża kruszywa naturalnego (piasku z domieszką żwiru) Łubienica X. Centralne Archiwum Geologiczne, Państwowy Instytut Geologiczny - Państwowy Instytut Badawczy, Warszawa.

Przybylski G., 2008a. Dodatek nr 3 do dokumentacji geologicznej złoża kruszywa naturalnego (piasków ze żwirem) Łubienica II w kat. C1. Centralne Archiwum Geologiczne, Państwowy Instytut Geologiczny - Państwowy Instytut Badawczy, Warszawa.

Przybylski G., 2008b. Dodatek nr 4 do dokumentacji geologicznej złoża kruszywa naturalnego (piasków ze żwirem) Łubienica II w kat. C1. Centralne Archiwum Geologiczne, Państwowy Instytut Geologiczny - Państwowy Instytut Badawczy, Warszawa.

Przybylski G., 2008c. Dodatek nr 5 do dokumentacji geologicznej w kat. C1 złoża kruszywa naturalnego (piasku z domieszką żwiru) Łubienica V - pole A i pole C. Centralne Archiwum Geologiczne, Państwowy Instytut Geologiczny - Państwowy Instytut Badawczy, Warszawa.

Przybylski G., 2008d. Dodatek nr 1 do dokumentacji geologicznej w kat. Cl złoża kruszywa naturalnego (piasku ze żwirem) Łubienica XI. Centralne Archiwum Geologiczne, Państwowy Instytut Geologiczny - Państwowy Instytut Badawczy, Warszawa.

Przybylski G., 2008e. Dokumentacja geologiczna złoża kruszywa naturalnego Łubienica XIII w kat. C1. Centralne Archiwum Geologiczne, Państwowy Instytut Geologiczny - Państwowy Instytut Badawczy, Warszawa.
Różycki S.Z., 1972. Plejstocen Polski środkowej na tle przeszłości w górnym trzeciorzędzie. W: Czwartorzęd Polski. PWN, Warszawa.

Russell A.J., Marren P.M., 1999. Proglacial fluvial sedimentary sequences in Greenland and Iceland: a case study from active proglacial environments subject to jökulhlaups, Skeiðararsandur, Iceland. Global and Planetary Change 28: 203-226.

Rutkowski J., 1995. Badania uziarnienia osadów bardzo gruboziarnistych. W: E. Mycielska-Dowgiałło, J. Rutkowski (red.), Metody badań osadów czwartorzędowych. Wybrane metody i interpretacja wyników. Wydawnictwo WGSR UW, Warszawa: 106-114.

Sambrook-Smith G.H., 2000. Small-scale cyclicity in alpine proglacial fluvial sedimentation. Sedimentary Geology 132: 217-231.

Smolska E., Szwarczewski P., Giriat D., Borkowski K., 1998. Texture characterization of the contemporary coarse clastic outwash sediments of Flaajokull and Falljokull in south-eastern Iceland. Miscellanea Geographia 8: 55-65.

Szmańda J., 2011. Zapis warunków depozycji w uziarnieniu aluwiów pozakorytowych. Landform Analysis 18.

Visher G.S., 1969. Grain size distributions and depositional processes. Journal of Sedimentary Petrology 39: 1074-1106.

Zieliński T., 1993. Sandry Polski północno-wschodniej - osady i warunki sedymentacji. Wydawnictwo UŚ, Katowice.

Zieliński T., 1995. Kod litofacjalny i litogenetyczny - konstrukcja i zastosowanie. W: E. Mycielska-Dowgiałło, J. Rutkowski (red.), Badania cech teksturalnych osadów czwartorzędowych i wybrane metody oznaczania ich wieku. Wydawnictwo Szkoły Wyższej Przymierza Rodzin, Warszawa: 220-235

Zieliński T., 1998. Litofacjalna identyfikacja osadów rzecznych. W: E. Mycielska-Dowgiałło (red.), Struktury sedymentacyjne i postsedymentacyjne $\mathrm{w}$ osadach czwartorzędowych i ich wartość interpretacyjna. Wydawnictwo UW, Warszawa: 195-260.

Zieliński T., 2014. Sedymentologia. Osady rzek i jezior. Wydawnictwo UAM, Poznań: 1-594.

Zieliński T., Pisarska-Jamroży M., 2012. Jakie cechy litologiczne warto kodować, a jakie nie? Przegląd Geologiczny 60: 387-397.

Zieliński T., van Loon A.J., 2003 Pleistocene sandur deposits represent braidplains, not alluvial fans. Boreas 32: 590-611. 